\title{
Fibre components negatively affect ileal protein digestibility in pigs ${ }^{*}$
}

\author{
L. Buraczewska \\ The Kielanowski Institute of Animgl Physiology and Nutrition, \\ Polish Academy of Sciences \\ 05-110 Jablonna, Poland
}

\begin{abstract}
The composition and properties of different NSP fractions of grain legumes, cereals and rapeseed meal are described and their implications in ileal digestibility of protein and amino acids in pigs are discussed. The effects of exogenous carbohydrases added to the diets of young pigs on protein digestibility are presented.
\end{abstract}

KEY WORDS: pigs, dietary fibre, NSP, NDF, amino acids, ileal digestibility

\section{INTRODUCTION}

Cereal grains constitute the bulk of pig feedstuffs and provide $30-60 \%$ of dietary amino acids. Protein should be added to the diet to provide both an adequate amount of total protein and amino acids in proportions approaching the ideal amino acid pattern. Protein feedstuff must now be of plant origin because animal meals are to be completely excluded from animal feeds. All plant feedstuffs contain considerable amounts of non-starch polysaccharides (NSP), lignin, oligosaccharides, which cannot be digested by endogenous mammalian enzymes. NSP, the principal component of dietary fibre (DF) and of cell walls, can affect many processes along the entire gastrointestinal tract (Low, 1985; Graham et al., 1990; Rakowska et al., 1992; Simon, 1998; Smulikowska, 1998). The physiological effects of NSP depend on their composition and physicochemical properties (e.g., solubility, water-

\footnotetext{
* Supported by the State Committee for Scientific Research, Grant No. 5P06E 01917
} 
holding capacity, fermentability). In general, viscous polysaccharides reduce absorption in the small intestine, whereas insoluble cell-wall polysaccharides have a smaller impact on this process but encapsulate nutrients (protein, starch) decreasing their hydrolysis.

Dietary fibre also contains various types of protein (Bjergegaard et al., $1997 \mathrm{a}, \mathrm{b}$ ). Many authors investigated the negative correlation between fibre content in feedstuffs and ileal digestibility of protein and amino acids in pigs (Taverner and Farrel, 1981; Eggum and Beames, 1983; Gdala et al., 1992; Fan et al., 2001). It was documented that protein association with fibre is one of the important factors causing large variability in digestibility values.

By encapsulating or binding protein, insoluble NSP form a physical barrier to endogenous enzymes. On the other hand, the water soluble fraction of NSP increases the viscosity of the digesta in the small intestine, decreasing nutrient absorption. Thus, there is a basis for the action of exogenous NSP hydrolyzing enzymes. There is a wealth of data reporting significant improvement of the feeding value of cereals supplemented with various enzymes in diets for poultry. There are also many examples of beneficial effects of exogenous enzymes used in the nutrition of young pigs (Partridge, 2001).

This paper will review the composition and properties of different NSP fractions of the main plant-origin feedstuffs, their implication in ileal digestibility of protein and amino acids and some positive effects of exogenous carbohydrase enzymes used in diets for young pigs.

\section{DIVERSITY AND FRACTIONS OF FIBRE IN FEEDSTUFFS}

All plant feedstuffs used in pig nutrition contain non-starch polysaccharides which together with lignin constitute the main part of dietary fibre. All DF components are resistant to mammalian hydrolases. According to Bach Knudsen (1997), NPS can be classified as cell wall NSP and non-cell wall NSP. Taking into account chemical composition, the first group of NSP consists of: cellulose, mixed linked $\beta$-glucans, arabinoxylans, arabinogalactans, xyloglucans, rhamnogalacturans and galactans occurring in different proportions in most feedstuffs. The non-cell wall NSP are represented by fructans (e.g., in rye), mannans (e.g., in coconuts and palm cakes), pectins (e.g., in bect pulp and lupins) and galactomannans (e.g., in guar-gum).

Further separation of DF can be obtained by sequential extraction of fibre in water, alkaline solution and sulphuric acid resulting in the following fractions: pectins, hemicelluloses, cellulose and lignin (Bjergegaard et al., 1997b). Each of these fractions comprises heterogeneous groups of compounds, varying with the DF source. They differ not only between plant species and varieties but also 
change due to environmental factors as well as stage of plant cell maturity (Theander and Åman, 1979).

Over the years, plant fibre has also been classified by using the terms crude fibre (CF), consisting mainly of lignin and cellulose, acid detergent fibre (ADF), of similar composition to $\mathrm{CF}$, and neutral detergent fibre (NDF) in which cellulose, hemicelluloses and lignin dominate, but some $\beta$-glucans, pectins and proteins are also present (Goering and Van Soest, 1970, after Fan et al., 2001).

As shown by $\AA$ man et al. (1988), each analytical method determines a specific fraction of the fibre present, with no close relationships between DF, NDF, ADF and $C F$ for different feeds. In general, however, NDF accounts for about $80-90 \%$ of DF while ADF and CF usually account for $20-30 \%$ of total fibre, estimated as the remainder after subtracting the content of free sugars, starch, crude protein, crude fat and ash from the dry matter of the sample.

Additionally, DF may also be divided into soluble and insoluble fractions with different physicochemical properties (Asp et al., 1983). However, the physiological and nutritional properties of DF depend not only on its composition but also on the micromolecular organization of the fibre complex in the cell wall, and are often characterized using parameters like solubility, viscosity, water-holding capacity and cation-exchange capacity. Soluble polysaccharides, in contrast to insoluble fibre, may cause viscous conditions in the upper part of the digestive tract and negatively affect digestive processes (Antoniou et al., 1981).

Plant cell walls, the dominating part of DF, contain not only NSP but also various types of proteins, lipids, amphiphilic compounds and phenolics, including lignin.

\section{DIETARY FIBRE-ASSOCIATED PROTEINS, GLYCOPROTEINS}

In the DF of many feedstuffs, the total amount of protein may account for 10 to $30 \%$ of the DF mass. For example, the DF of pea has a low protein content, while the DF of rape seed has a high content (Bjergegaard and Sørensen, 1995: Bjergegaard et al., 1997b). DF or cell-wall proteins were classified as structural proteins (comprising glycoproteins, arabinogalactan proteins, proline- and glycine-rich proteins), lectins and enzymes (Bjergegaard et al., 1997a).

Among glycoproteins that are often the dominating group, compounds called extensins are prominent. They resemble collagen and form crosslinked networks with each other as well as with cellulose microfibrils (Fry, 1988; Keller, 1993; Showalter, 1993). These structures reduce the solubility of extensins and make them more resistant towards mammalian-produced hydrolases. This can be part of the explanation of the relatively low protein digestibility of rape seed (Danielsen et al., 1994). Also, after rupture of the cell, intracellular glycoproteins may be bound to DF components, thus increasing the part of indigestible protein in rape seed. 


\section{EFFECTS OF NDF ON PROTEIN DIGESTION IN PIGS}

\section{Grain legumes}

Gdala et al. (1998) examined the relationship between the NDF-associated protein content of pea, faba bean and lupin grains and ileal digestibility of protein and amino acids in growing pigs. The results given in Table 1 show that lupins (three species) contain significantly more NDF and ADF than pea and faba bean. The

TABLE 1

Relationship between the NDF-protein content in grain legumes and apparent ileal digestibility of protein and amino acids in pigs ( $\mathrm{n}=$ varieties of pea and faba bean, species of lupin, Gdala et al., 1998)

\begin{tabular}{lcccc}
\hline Item & $\begin{array}{c}\text { Pea } \\
\mathrm{n}=4\end{array}$ & $\begin{array}{c}\text { Faba bean } \\
\mathrm{n}=3\end{array}$ & $\begin{array}{c}\text { Lupins } \\
\mathrm{n}=3\end{array}$ & SEM \\
\hline Chemical composition & & & & \\
$\mathrm{N} 6.25 \mathrm{~g} / \mathrm{kg} \mathrm{DM}$ & $229.8^{\mathrm{b}}$ & $296.2^{\mathrm{ab}}$ & $360.0^{\mathrm{a}}$ & 9.40 \\
$\mathrm{NDF}, \mathrm{g} / \mathrm{kg} \mathrm{DM}$ & $142.4^{\mathrm{c}}$ & $191.0^{\mathrm{b}}$ & $237.4^{\mathrm{a}}$ & 5.84 \\
$\mathrm{NDF}-$ protein, \% NDF & $9.3^{\mathrm{a}}$ & $12.2^{\mathrm{a}}$ & $5.0^{\mathrm{b}}$ & 0.48 \\
NDF-protein, \% total protein & $7.8^{\mathrm{a}}$ & $8.5^{\mathrm{a}}$ & $2.9^{\mathrm{b}}$ & 0.48 \\
& & & & \\
lleal digestibility, \% & & & $86.5^{\mathrm{a}}$ & 0.41 \\
crude protein & $70.9^{\mathrm{b}}$ & $70.0^{\mathrm{b}}$ & $76.9^{\mathrm{a}}$ & 1.26 \\
threoninc & $62.0^{\mathrm{b}}$ & $66.9^{\mathrm{b}}$ & $89.2^{\mathrm{a}}$ & 0.76 \\
isoleucine & $70.0^{\mathrm{b}}$ & $74.2^{\mathrm{b}}$ & $82.2^{\mathrm{a}}$ & 1.32 \\
leucine & $71.7^{\mathrm{b}}$ & $76.0^{\mathrm{b}}$ & $86.9^{\mathrm{a}}$ & 0.64 \\
histidine & $76.8^{\mathrm{b}}$ & $77.8^{\mathrm{b}}$ & $90.8^{\mathrm{a}}$ & 1.98 \\
methionine & $58.1^{\mathrm{b}}$ & $60.5^{\mathrm{b}}$ & $67.7^{\mathrm{a}}$ & 1.64 \\
tryptophan & $46.8^{\mathrm{b}}$ & $50.1^{\mathrm{b}}$ & 79.8 & 2.33 \\
lysine & 81.1 & 80.4 & & \\
\hline
\end{tabular}

a. b $-\mathrm{P}<0.05$

NDF-protein constituted on average 12.2, 9.3 and 5.0\% of NDF in faba bean, pea and lupins, respectively, which is more than in cereals, for which reported protein values ranged from 1.6 to $5.4 \%$ of NDF (Hall et al., 1987). The values of protein and also amino acids of the NDF fraction, expressed as a percent of their total content in legumes, were slightly higher for faba beans than peas; the lowest values were found for lupins. Moreover, in comparison with the amino acid composition of total seed protein, significantly $(\mathrm{P}<0.05)$ more threonine and valine were found in the protein bound to the NDF fraction of all tested grain legumes.

Digestibility data (Table 1) show that lupins containing the highest level of NDF had the highest apparent ileal digestibility of protein $(86.5 \%)$ and of most 
amino acids. Peas and faba beans, despite a lower NDF content than lupin, had lower ileal protein digestibility ( 70.9 and $70.0 \%$, respectively) and, with the exception of lysine, also lower amino acid digestibility. It seems that higher apparent digestibility values of lysine resulted from the different (higher) level of this amino acid in the protein of those legumes. The reduced ileal digestibility of pea and faba bean protein, as compared with lupin protein, can be explained in about $70 \%$ by the content of NDF-bound protein in the legumes. The correlation coefficient found between apparent ileal digestibility of protein and the NDF-protein content of the legumes was $r=-0.840$ at $\mathrm{P}<0.05$.

In experiments on growing pigs, Gdala et al. (1992) found that ileal digestibility of protein of different pea cultivars ( 10 cultivars were compared) was significantly affected by NDF content. Also Fan and Sauer (1999) recently showed that the ileal digestibility values of the majority of the indispensable amino acids were negatively correlated with the NDF content in pea samples that originated from six cultures located in different places in Canada. However, in an earlier experiment, inclusion of isolated pea carbohydrates into diets for piglets did not affect apparent ileal protein digestibility but decreased dry matter digestibility of the test diets containing three protein sources (Huisman and Le Guen, 1991).

It may be concluded that NDF-associated protein negatively affects the ileal digestibility of protein and amino acids of different grain legumes in growing pigs.

\section{Cereals}

Many authors reported that differences in the DF content of cereals were responsible for a considerable part of the variation in ileal digestibility values of protein and amino acids. Taverner and Farrell (1981) found that the NDF content in cereal grain negatively influenced the availability of amino acids to pigs. A negative relationship between protein digestibility and fibre content in cereal grains was also found by Eggum and Beames (1983) in studies with pigs and rats.

The effect of variation in fibre content in wheat fractions on protein and amino acid digestibility in pigs was studied by Jondréville et al. (1995) and recently by Huang et al. (1999). In the earlier studies on wheat fractions containing from about 7 to $48 \% \mathrm{NDF}$, they found negative correlations between ADF content, or proportion of total $\mathrm{N}$ bound to NDF, and true ileal digestibilities of crude protein and all amino acids. Less pronounced correlations (Table 2) were found between NDF level and apparent ileal digestibility values in wheat fractions composed by taking different proportions of wheat bran, shorts and flour, containing from 29.5 to $42.3 \%$ NDF (on a DM basis). However, the digestibilities were usually lowest in the wheat fractions containing wheat bran. These results are in general agreement with those reported by Graham et al. (1986a) who found that the dietary inclusion of wheat 
TABLE 2

The neutral detergent fibre content (\% DM) and apparent ileal digestibility (\%) of crude protein and limiting amino acids in the wheat fractions (Huang et al., 1999)

\begin{tabular}{lcccccc}
\hline \multirow{2}{*}{ Item } & \multicolumn{5}{c}{ Wheat fraction } & \multirow{2}{*}{ SEM $^{\text {l }}$} \\
\cline { 2 - 6 } & $\mathrm{A}$ & $\mathrm{B}$ & $\mathrm{C}$ & $\mathrm{D}$ & $\mathrm{E}$ & \\
\hline Wheat shorts, \% & 70 & 85 & 100 & 85 & 70 \\
Wheat bran, \% & 30 & 15 & - & - & - & \\
Wheat flour, \% & - & - & - & 15 & 30 & \\
NDF & 42.3 & 41.8 & 41.3 & 35.2 & 29.5 & \\
& & & & & & \\
Digestibility & & & & & & \\
crude protein & $59.2^{\mathrm{b}}$ & $61.4^{\mathrm{bc}}$ & $62.9^{\mathrm{bc}}$ & $68.6^{\mathrm{c}}$ & $67.6^{\mathrm{c}}$ & 1.88 \\
lysine & 54.7 & 59.3 & 62.0 & 64.1 & $57.2^{\mathrm{n}}$ & 2.95 \\
methionine & $72.2^{\mathrm{b}}$ & $77.8^{\mathrm{bc}}$ & $76.8^{\mathrm{bc}}$ & $80.3^{\mathrm{c}}$ & $79.3^{\mathrm{bc}}$ & 1.47 \\
cystine & $63.2^{\mathrm{b}}$ & $64.7^{\mathrm{b}}$ & $60.4^{\mathrm{b}}$ & $73.6^{\mathrm{c}}$ & $66.7^{\mathrm{bc}}$ & 2.42 \\
threonine & $48.9^{\mathrm{b}}$ & $57.2^{\mathrm{bc}}$ & $62.4^{\mathrm{c}}$ & $69.2^{\mathrm{c}}$ & $67.8^{\mathrm{c}}$ & 3.00 \\
\hline
\end{tabular}

a - standard error of the mean

b.c.d - means in the same row with different superscript letter differ at $\mathrm{P}<0.05$

bran depressed the ileal digestibility of crude protein. In studies on pigs fed purified diets containing NDF from wheat, ileal protein digestibility decreased by 4.9 percentage units when $18 \%$ NDF was included (Schulze et al., 1994). A similar effect was observed by Lenis et al. (1996) in pigs fed a diet containing 15\% NDF.

In a recently published paper, Fan et al. (2001) evaluated the effect of NDF content on apparent ileal amino acid digestibility in six high-protein wheat samples given to growing-finishing pigs. Within each sample, the digestibility of lysine and threonine, the first and second limiting amino acid, were the lowest among the indispensable amino acids and ranged from 54 to $70 \%$ and 64 to $73 \%$, respectively. There was also considerable variation in the digestibility values of other amino acids. The digestibility values of most indispensable amino acids were negatively correlated $(\mathrm{P}<0.05)$ with NDF content. Differences in NDF content in wheat ranging from 11.7 to $17.8 \%$ were, in part, responsible for the variation in the determined digestibilities. The authors suggested that in the wheat samples, different proportions of low digested proteins, deposited in the aleurone layer, the pericarp and the seed coat (together about $20 \%$ of total wheat protein) could be responsible for the digestibility variations. In studies with wheat shorts, it was demonstrated earlier (Huang, 1997, after Fan et al., 2001) that considerable proportions of crude protein and amino acids are directly associated with NDF and are of low digestibility.

The lower ileal digestibility of protein and amino acids with increasing waterinsoluble fibre may be attributed to the accelerated passage of digesta (Stanogias and Pearce, 1985) and increased ileal recovery of endogenous nitrogen compounds 
(De Lange et al., 1989; Furuya and Kaji, 1992; Grala et al., 1998). Different mechanisms of influence on digestive processes are suggested for water-soluble fibre. Its viscosity can decrease the digestion and absorption of nutrients by reducing the mixing of intestinal digesta, thus blocking enzyme-substrate interaction and lowering nutrient absorption (Bedford and Classen, 1992; Choct and Annison, 1992).

The effect of soluble fibre content on results of ileal digestibility of DM, protein and limiting amino acids was observed in pigs fed rye with a low $(3.8 \%)$ or high level $(5.8 \%)$ of soluble dietary fibre (SDF) (Table 3 ). The viscosity of the high-SDF rye was more than 3 times higher than that of low-SDF rye. All digestibility values were significantly lower for both samples of rye than for wheat, used as a control cereal, and were usually the lowest in the cereal containing the highest SDF level. Similar values of methionine digestibility in both samples of rye can be explained by the higher content of this amino acid in protein $(2.07 \mathrm{vs} 1.83)$ and in the DM of high-SDF-rye than in low-SDF-rye.

According to our recent results, a high viscosity of digesta in pigs does not always affect protein and amino acid digestibilities (Buraczewska et al., not published). The inclusion of carboxymethylcellulose instead of crystalline cellulose into semisynthetic diets increased the viscosity of ileal digesta from 1.82 to

TABLE 3

Dietary fibre content (\% DM) and apparent ileal digestibilities of dry matter, crude protein and limiting amino acids in wheat and in rye containing different levels of soluble dietary fibre (SDF) (Buraczewska and Wasilewko, not published)

\begin{tabular}{lccc}
\hline & Wheat & Low-SDF rye & High-SDF rye \\
\hline $\begin{array}{l}\text { Dietary fibre } \\
\text { insoluble }\end{array}$ & 10.16 & & \\
soluble & 2.00 & 3.80 & 16.56 \\
total & 12.16 & 19.10 & 5.60 \\
& & & 22.16 \\
Klason lignin & 2.13 & 2.89 & 3.18 \\
Viscosity' & 24 & 1270 & 4284 \\
& & & \\
Digestibility & & & $55.1^{\mathrm{C}}$ \\
dry matter & $77.2^{\mathrm{A}}$ & $61.4^{\mathrm{B}}$ & $65.9^{\mathrm{C}}$ \\
crude protein & $81.7^{\mathrm{A}}$ & $70.4^{\mathrm{B}}$ & $62.8^{\mathrm{B}}$ \\
lysine & $86.7^{\mathrm{A}}$ & $64.9^{\mathrm{B}}$ & $78.8^{\mathrm{B}}$ \\
methionine & $86.8^{\mathrm{A}}$ & $78.4^{\mathrm{B}}$ & $65.2^{\mathrm{C}}$ \\
cystine & $84.6^{\mathrm{A}}$ & $76.7^{\mathrm{B}}$ & $54.1^{\mathrm{C}}$ \\
threonine & $72.5^{\mathrm{A}}$ & $59.8^{\mathrm{B}}$ & $62.5^{\mathrm{C}}$ \\
tryptophan & $79.4^{\mathrm{A}}$ & $68.0^{\mathrm{B}}$ & \\
\hline
\end{tabular}

' expressed in mPas, measured with Theotest -2

$\mathrm{A}, \mathrm{B}, \mathrm{C}-\mathrm{P} \leq 0.01$ 
$649.5 \mathrm{mPas}$, but had no effect on ileal digestibility of soyabean protein (Table 4). On the other hand, in the cereal based diets, reduction of viscosity from 10.6 to $3.3 \mathrm{mPas}$ by xylanase supplementation significantly increased all determined ileal digestibility values.

TABLE 4

Viscosity of ileal digesta (in mPas) and apparent ileal digestibility of DM, protein, NDF and gross energy in young pigs (20-25 $\mathrm{kg} \mathrm{BW}$ ) fed two purified diets ( $\mathrm{C}$ and $\mathrm{CMC})^{\prime}$ and two cereal diets (RW and $\mathrm{RWE})^{2}, \%$

\begin{tabular}{lcccc}
\hline Item & $\mathrm{C}$ & $\mathrm{CMC}$ & $\mathrm{RW}$ & $\mathrm{RWE}$ \\
\hline Viscosity of ileal digesta & $1.82^{\mathrm{A}}$ & $649.5^{\mathrm{f}}$ & $10.6^{\mathrm{b}}$ & $3.3^{\mathrm{a}}$ \\
& & & & \\
Ileal digestibility & 85.9 & 84.8 & $70.9^{\mathrm{a}}$ & $73.9^{\mathrm{b}}$ \\
dry matter & 85.1 & 85.0 & $77.7^{\mathrm{a}}$ & $79.4^{\mathrm{b}}$ \\
crude protein & & & $43.7^{\mathrm{a}}$ & $52.2^{\mathrm{b}}$ \\
NDF & 90.7 & 90.2 & $82.1^{\mathrm{a}}$ & 86.5 \\
energy & &
\end{tabular}

1 two similar diets: one contained $5 \%$ crystalline cellulose (C) and one was with $3 \%$ cellulose and $2 \%$ carboxymethylcellulose of high viscosity (CMC)

${ }^{2}$ two similar rye-wheat diets: one without enzyme (RW) and one supplemented with xylanase (ZY68) at a level of $0.4 \mathrm{~g}$ per $\mathrm{kg}$ (RWE)

\section{Rapeseed meal}

A negative correlation between NDF-content and apparent ileal amino acid digestibility values was found in canola meal (Fan et al., 1996) and in rapeseed meal (Buraczewska et al., 1998). In our study, the contents of NDF and of the NDFprotein and its amino acid composition were determined in rapeseed cake and rapeseed meal heated at $130^{\circ} \mathrm{C}$ for $0,20,40,60$ and $80 \mathrm{~min}$, and the same components were also determined in commercial rapeseed meals of different origin. The NDF content of rapeseed cake and meal increased with increasing duration of heating. After $80 \mathrm{~min}$, the NDF in rapeseed cake increased from 21 to $34 \%$ and that in meal increased from 26 to $38 \%$. At the same time, a nearly two-fold increase in the protein content of the meal and cake NDF fraction was observed. The content of NDF-bound protein expressed as a percent of total protein, ranged from $10 \%$ in the meal from yellow-seeded spring rape (Brassica rapa L.) to $18 \%$ in the industrial rapeseed meal (Brassica napus L.).

The apparent ileal digestibility of protein and amino acids of industrial rapeseed meals decreased with increasing NDF content in the meals (Table 5). The highest digestibility values were found in Canadian (canola) and Finnish meals containing the lowest level of NDF (25.7 and 26.5\%), while the lowest digestibility was found in two Polish commercial meals with the highest level (32 and 38\%) 
TABLE 5

Apparent ileal digestibility of protein and amino acids (\%) of rapeseed meals differing in NDF content, fed in semisynthetic diets to growing pigs (Buraczewska et al., 1998)

\begin{tabular}{|c|c|c|c|c|c|c|}
\hline & \multicolumn{6}{|c|}{ Rapeseed meals } \\
\hline & Canola' & RSM-F ${ }^{2}$ & $\mathrm{RSM}-1^{3}$ & $\mathrm{RSM}-2^{4}$ & RSM-3 $3^{5}$ & $\operatorname{RSM}-4^{6}$ \\
\hline NDF, $\% \mathrm{DM}$ & 25.7 & 26.5 & 27.1 & 30.1 & 32.3 & 38.1 \\
\hline \multicolumn{7}{|l|}{ Ileal digestibility } \\
\hline crude protein & 69.5 & 72.4 & 64.4 & 64.6 & 59.5 & 57.6 \\
\hline lysine & 76.5 & 72.3 & 69.5 & 66.7 & 61.8 & 49.6 \\
\hline methionine & 80.7 & 86.1 & 77.4 & 80.0 & 75.3 & 74.3 \\
\hline cystine & 76.6 & 71.7 & 68.4 & 66.8 & 60.5 & 58.3 \\
\hline threonine & 65.5 & 70.2 & 65.0 & 63.3 & 57.2 & 56.3 \\
\hline tryptophan & 67.8 & 74.5 & 63.3 & 63.9 & 58.0 & 59.8 \\
\hline $\begin{array}{l}1 \text { meal from Can } \\
2 \text { meal from Fin } \\
{ }^{3} \text { experimental } n \\
{ }^{4} \text { experimental } n \\
5.6 \text { commercial } n\end{array}$ & from oil & $\begin{array}{l}\text { ory Szam } \\
\text { ory Krusz }\end{array}$ & $\begin{array}{l}\text {, toasted a } \\
\text {, toasted a }\end{array}$ & $\begin{array}{l}0^{\circ} \mathrm{C} \\
0-95^{\circ} \mathrm{C}\end{array}$ & & \\
\hline
\end{tabular}

of NDF. It was concluded that rapeseed meals containing more than $30 \% \mathrm{NDF}$ are over-heated during fat extraction and toasting and that they have a relatively low nutritive value, as indicated by apparent ileal digestibility.

\section{EFFICACY OF EXOGENOUS CARBOHYDRASE ENZYMES IN PROTEIN DIGESTION}

Soluble NSP are present in considerable amounts in barley, rye, wheat, triticale and oat. As the dominating soluble NSP are mixed-linked ( $B 1,3$ and $B 1,4$ linkages) $\beta$-glucan and arabinoxylans occurring in different proportions and levels, enzyme preparations with B-glucanase and arabinoxylanase (xylanase) activities are most commonly used to decrease their antinutritive effect. The use of xylanase for wheat and B-glucanase for barley in poultry feeding is a common practice. Generally, most of the enzymes effectively depolymerize the soluble NSP into smaller polymers, though some products with affinity for both soluble and insoluble NSP are also used (e.g. , hemicellulase, pectinase, $\alpha$-galactosidase).

Enzyme supplementation of different types of diets is less effective and consistent in pigs than in poultry (Graham et al., 1986 b; Bedford et al., 1992). However, there are results showing that addition of $\beta$-glucanase, xylanase and protease to hull-less barley diets for $15-35 \mathrm{~kg}$ pigs significantly increased ileal digestibility of dry matter, gross energy, protein, amino acids and NSP (Liu et al., 1997). The 
supplementation of hull-less barley only with B-glucanase also resulted in significant improvement in the digestibility of protein and energy. A linear increase in the digestibility values of dry matter, protein and energy was observed when increasing levels $(0.05,0.1$ and $0.2 \%)$ of $\beta$-glucanase were added to the barley-soyabean meal diets, but significant improvement in protein digestibility (increase by 6.9 percentage units) was recorded only for the highest enzyme supplementation. Increased ileal digestibility of protein after enzyme supplementation of barley diets was found also in recent studies (Baidoo et al., 1998; Yin et al., 2000). The positive response of wheat, triticale and rye to exogenous enzymes in pigs seems to depend on the feeding value of cereals, e.g., poor value wheat was significantly improved by xylanase supplementation (Choct et al., 1999; Partridge et al., 1999). Relatively few studies have been reported on the effects of exogenous enzymes on diets containing maize and sorghum in which insoluble arabinoxylans comprise over $40 \%$ of NSP. Positive responses were found both after addition to maize-based diet of a complex enzyme blend containing protease, cellulase, pentosanase, galactosidase and amylase (Lindemann et al., 1997) or xylanase (Schulze et al., 1996; Partridge et al., 1999). Gdala et al. (1997) examined the effect of $\alpha$-galactosidase $(0.5 \%)$ supplementation to the diet containing $35 \%$ lupin. The enzyme significantly increased not only hydrolysis of $\alpha$-galactosides but also ileal digestibility of most amino acids.

In many experiments there were no positive effects of enzyme supplementation. To obtain a benefit, the added enzyme must be active along the whole small intestine and resist proteolysis by digestive enzymes. Differences in the anatomy and physiology of the digestive tract between pigs and poultry are such that exogenous enzymes find dissimilar environments during passage along the gut. According to Dierick and Decuypere (1996) and Bedford and Schulze (1998) these differences include the following: 1. anatomy; 2 . digestive capacity; 3 . bacterial activity; 4. fibre fermentation. In poultry, feed stays in the crop for several hours; there enzymes can act at a $\mathrm{pH}$ of approximately 6.0 before the digesta passes into the acid environment of the gizzard, whereas in pigs, feed passes directly into the stomach with a low $\mathrm{pH}$. Birds have a shorter small intestine than the pig and thus reduced possibilities for enzyme inactivation. The importance of poultry gut microflora is much less than in the pig, and fibre fermentation in poultry is lower.

It seems that more attention should be paid to description of dictary components, particularly fibre analysis and properties, as well as enzyme sources and levels to receive the cost-effective responses to enzyme supplementation. Moreover, better understanding is needed of the role that enzymes have to play in gut physiology, particularly aspects such as digesta passage rate and patterns of fermentation in the fore- and hindgut in the pig. More experiments should be carried out on the use of appropriate enzymes in novel pig feeding applications involving pretreatments of raw materials, with or without the use of liquid feeding systems. 


\section{REFERENCES}

Åman P., Graham H., Löwgren W., 1988. Dictary fibre in pig feeds. Proceedings of the $4^{\text {th }}$ International Symposium on Digestive Physiology in the Pig. Jablonna (Poland), pp. 120-127

Antoniou T., Marquardt R.R., Cansfield P.E., 1981. Isolation, partial characterisation, and antinutritional activity of a factor (pentosans) in rye grain. J. Agr. Food Chem. 29, 1240-1247

Asp N.G., Johansson C.G., Hallmer H., Siljeström M., 1983. Rapid enzymatic assay of insoluble and soluble dietary fibre. J. Agr. Food Chem. 31, 476-482

Bach Knudsen K.E., 1997. Carbohydrates and lignin contents of plant materials used in animal fecding. Anim. Feed Sci. Tech. 67, 319-338

Baidoo S.K., Lui J.G., Grandhi R.R., 1998. Exogenous enzymes and hulless barley utilization by young pigs. Proceedings of the 1998 Feed Grain Quality Conference, Edmonton (Canada), pp. $67-71$

Bcdford M.R., Classen H.L., 1992. Reduction of intestinal viscosity through manipulation of dietary rye and pentosanase concentration is effected through changes in the carbohydrate composition of the intestinal aqueous phase and results in improvement growth rate and food conversion efficiency of broiler chicks. J. Nutr. 122, 560-569

Bedford M.R., Patience J.F., Classen H.L., Inborr J., 1992. The effect of dietary enzyme supplementation in rye- and barley-based diets on digestion and subsequent performance in weanling pigs. Can. J. Anim. Sci. 72, 97-105

Bedford M.R., Schulze H., 1998. Egzogenous enzymes in pigs and poultry. Nutr. Res. Rev. 11, $91-$ 114

Bjergegaard C., Sørensen H., 1995. Characterization of proteins, including myrosinases associated to rapesced dietary fibres, compared to proteins in pea dietary fibres. Polish J. Food Nutr. Sci. 4 (2), $47-57$

Bjergegaard Ch., Sørensen H., Sørensen S., 1997a. Dietary fibres important parts of high quality food and feeds. Proceedings of the Symposium on Dietary Fibre - Chemical Composition and Biological Effects. Plant Breeding and Acclimatization Institute (Editor). Radzików (Poland), pp. $1-14$

Bjergegaard Ch., Sørensen H., Sørensen S., 1997b. Dietary fibres and associated compounds in rapeseed and biorefined rapeseed products compared to DF in pea. Proceedings of the Symposium on Dietary Fibre - Chemical Composition and Biological Effects. Plant Breeding and Acclimatization Institute (Editor). Radzików (Poland), pp. 41-57

Buraczewska L., Gala J., Wasilewko J., Buraczewski S., 1998. Ileal digestibility in pigs of protein and amino acids of heat treated rapeseed feeds as affected by protein associated with the fibre (NDF) fraction. Oilseed Crops XIX (I), 175-186

Choct M., Annison G., 1992. Anti-nutritive effect of wheat pentosans in broiler chickens: role of viscosity and gut microflora. Brit. Poultry Sci. 33, 821-834

Choct M., Cadogan D.J., Campbell R.G., Kershaw S., 1999. Enzymes can climinate the difference in the nutritive value of wheats for pigs. Proceedings of the $7^{\text {th }}$ Conference of the Australasian Pig Science Association. Adelaide (Australia), p. 39

Danielsen V., Eggum B.O., Jensen S.K., Sørensen H., 1994. Dehulled protein-rich rapeseed meal as protein source for early weaned piglets. Anim. Feed Sci. Tech. 46, 239-250

De Lange C.F.M., Sauer W.C., Mosenthin R., Souffrant W.R., 1989. The effect of feeding different protein-free diets on the recovery and amino acid composition of endogenous protein collected from the distal ileum and feces in pigs. J. Anim. Sci. 67, 746-754

Dierick N., Decuypere J., 1996. Mode of action of exogenous enzymes in growing pig nutrition. Pig News Inf. $17,41 \mathrm{~N}-48 \mathrm{~N}$ 
Eggum B.O., Beames R.M., 1983. The nutritive value of seed proteins. In: W. Gottschalk, H.P. Müller, H.P. Matinus Nijhoff, W. Junk (Editors). Seed Proteins - Biochemistry, Genetics, Nutritive Values (The Netherlands), pp. 499-531

Fan M.Z., Sauer W.C., 1999. Variability of apparent ileal amino acid digestibility in different pea samples for growing-finishing pigs. Can. J. Anim. Sci. 79, 467-474

Fan M.Z., Sauer W.C., Gabert V.M., 1996. Variability of apparent ileal amino acid digestibility in canola meal for growing pigs. Can. J. Anim. Sci. 76, 563-569

Fan M.Z., Sauer W.C., Li S., 2001. Variability of apparent ileal amino acid digestibility in highprotein wheat samples for growing-finishing pigs. J. Anim. Feed Sci. 10, 103-118

Fry S.C., 1988. The Growing Plant Cell Wall. Chemical and Metabolic Analysis. Longman Scientific and Technical, Harlow (UK)

Furuya S., Kaji Y., 1992. The effect of feed intake and purified cellulose on the endogenous ileal amino acid flow in growing pig. Brit. J. Nutr. $68,463-472$

Gdala J., Buraczewska L., Grala W., 1992. The chemical composition of different types and varieties of pea and the digestion of their protein in pigs. J. Anim. Feed Sci. 1, 71-78

Gdala J., Buraczewska L., Wasilewko J., 1998. Relationship between the NDF-protein content of legumes and ileal digestibility of protein and amino acids in pigs. Proceedings of the $3^{\text {td }}$ European Conference on Grain Legumes, Valladolid (Spain), pp. 384-385

Gdala J., Jansman A.J.M., Buraczewska L., Huisman J., Van Leeuven P., 1997. The influence of $\alpha$-galactosidase supplementation on the ileal digestibility of lupin seed carbohydrates and dietary protein in young pigs. Anim. Feed Sci. Tech. 67, 115-125

Graham H., Åman P., Patterson D., 1990. Chemical analysis and nutritional aspects of dietary fibre. Comp. Physiol. 5, 242-253

Graham H., Hesselman K., Åman P., 1986a. The effect of wheat bran and sugar beet pulp on the digestibility of dietary components in a cereal-based pig diet. J. Nutr. 116, 242-251

Graham H., Hesselman K., Jonnson E., Åman P., 1986b. Influence of $\alpha$-glucanase supplementation on digestion of barley-based diet in the pig gastrointestinal tract. Nutr. Rep. Int. 34, 1089-1096

Grala W., Buraczewska L., Wasilewko J., Verstegen M.W.A., Tamminga S., Jansman A.J.M., Huisman J., Korczyński W., 1998. Flow of endogenous and exogenous nitrogen in different segments of the small inestine in pigs fed diets with soyabean concentrate, soyabean meal or rapeseed cake. J. Anim. Feed Sci. 7, 1-20

Hall D.D., Fernández J.A., Jørgensen H., Boisen S., 1987. Prediction of ileal and faecal digestibility of crude protein and amino acids in pigs diets by NDF and NDF-nitrogen analyses. Wiss. Z. WPU. Rostock, N-Reihe 37 (1), 54-55

Huang S.X., Sauer W.C., Marty B., Hardin R.T., 1999. Amino acid digestibilities in different samples of wheat shorts for growing pigs. J. Anim. Sci. 77, 2469-2477

Huisman J., Le Guen M.P., 1991. Effects of pea ANF's and pea carbohydrates on ileal protein digestibility of piglets. Procecdings of the $5^{\text {th }}$ International Symposium on Digestive Physiology in Pigs. Wageningen (The Netherlands), pp. 60-65

Jondréville C., van den Broecke J., Gatel F., Bertin J.-M., Beaux M.-F., Grosjean F., 1995. Facteurs de variation de la digestibilité iléale de la protéine et des acides aminés d'issues de meunerie chez le porc charcutier. Journeés Rech. Porcine 27, 189-195

Keller B., 1993. Structural cell wall proteins. Plant Physiol. 104, 1127-1130

Lenis M.P., Bikker P., Van der Meulen J., Van Diepen J.T.M., Bakker J.G.M., Jongbloed A.W., 1996. Effect of dietary neutral detergent fibre on ileal digestibility and portal flux of nitrogen and amino acids and on nitrogen utilization in growing pigs. J. Anim. Sci. 74, 2687-2699

Lindemann M.D., Gentry J.J., Moncgue H.J., Cromwell G.L., Jacques K.A., 1997. Determination of the contribution of an enzyme combination (Vegpro) to performance in grower-finisher pigs. 
Proceedings of the $6^{\text {th }}$ Conference of the Australasian Pig Science Association. Canberra (Australia), p. 247

Liu Y.G., Baidoo S.K., Schulze H., 1997. Digestive responses of young pigs on microbial enzymes added to hulless barley diet; energy and amino acid digestibility. EAAP Publication No. 88, 462-465

Low A.G., 1985 Role of dietary fibre in pigs diets. In: W. Haresign, D.J.A. Cole (Editors). Recent Advances in Animal Nutrition. Butterworths, pp. 87-112

Partridge G.G., 2001. The role and efficacy of carbohydrase enzymes in pig nutrition. In: M.R. Bedford, G.G. Partridge (Editors). Enzymes in Farm Animal Nutrition. CABl Publishing, Wallingford, pp. 161-198

Partridge G.G., Simmins P.H., Cadogan D.J.. 1999. Influence of xylanase addition to diets containing wheat co-products and nutritionally deficient wheat on growing pig performance. Proceedings of the $7^{\text {th }}$ Conference of the Australasian Pig Science Associaton. Adelaide (Australia), p. 37

Rakowska M., Kupiec R., Rybka K., 1992. Studies on the antinutritive components in the rye grain. VI. Effect of dietary fibre fraction on protein digestibility in rats. Pol. J. Food Nutr. Sci. $1,103+107$

Schulze H., van Leeuven H.P., Verstegen M.W.A., Huisman J., Souffrant W.B., Ahrens F., 1994. Effect of level of dietary neutral detergent fibre on ileal apparent digestibility and ileal nitrogen losses in pigs. J. Anim. Sci. 72, 2362-2368

Schulze H., Partridge G.G., Creswell D., 1996. The effect of feed enzyme supplementation to corn soya based diets on performance of finisher pigs from 46 to $92 \mathrm{~kg}$. J. Anim. Sci. 74, Suppl.1, 191 (Abstr.)

Showalter A.M., 1993. Structure and function of plant cell wall proteins. Plant Cell 5, 9.23

Simon O., 1998. The mode of action of NSP hydrolysing enzymes in the gastrointestinal tract. J. Anim. Feed Sci. 7, Suppl.1, 115-123

Smulikowska S., 1998. Relationship between the stage of digestive tract development in chicks and the effect of viscosity reducing enzymes on fat digestion. J. Anim. Feed Sci. 7, Suppl. 1, $125-134$

Stanogias G., Pearce G.R., 1985. The digestion of fibre by pigs. 1. The effect of amount and type of fibre on apparent digestibility, nitrogen balance and rate of passage. Brit. J. Nutr. 53, 513-530

Taverner M.R., Farrell D.J., 1981. Availability to pigs of amino acids in cereal grains. 4. Factors influencing the availability of amino acids and energy in grain. Brit. J. Nutr. 46, 181-192

Theander O., Aman P., 1979. The chemistry, morphology and analysis of dietary fibre components. In: G.E. Inglett, S.J. Falkenag (Editors). Dietary Fibres: Chemistry and Nutrition. Academic Press Inc., New York, pp. 215-228

Yin Y.-L., McEvoy J.D.G., Schulze H., McCracken K.J., 2000. Studies on cannulation method and alternative indigestible markers and the effects of food enzyme supplementation in barley-based diets on ileal and overall apparent digestibility in growing pigs. Anim. Sci. 70, 63-72 
STRESZCZENIE

\section{Składniki włókna wpływają ujemnie na strawność bialka do końca jelita cienkiego u świń}

Dokonano przeglądu prac na temat składu i właściwości różnych frakcji polisacharydów nieskrobiowych znajdujących się w nasionach roślin motylkowych, ziarnach zbóż i w poekstrakcyjnych śrutach rzepakowych. Przedstawiono wpływ tych związków na strawność białka i aminokwasów do końca jelita cienkiego u świń. Podano także informacje o wpływie egzogennych enzymów rozkładających węglowodany w paszach dla rosnących świń na strawność jelitową białka i aminokwasów. 